\title{
圭目縫い絞りの発現に関する研究
}

\author{
岐阜大学工学部 内田 貴・岡村政明
}

\section{Study of the Generating Mechanism on Mokumenui-shibori Pattern}

\author{
Takashi Uchida ${ }^{* 1}$ and Masaaki Okamura*1
}

${ }^{* 1}$ Faculty of Engineering, Gifu University, Yanagido 1-1, Gifu 501-1193, Japan

\begin{abstract}
Shibori is the most primitive tie-dyeing technique that has been performed more or less in various regions of the world. There are many research works on historical background, pattern, and dyeing method of various types of Shibori. However, the generating mechanism of Shibori pattern has not been logically considered yet. The purpose of this study is to clarify the generation mechanism of a pattern of Mokumenui-shibori and to build up simulating system of Mokumenui-shibori. First, we considered the effect of stitching pattern on nine generated patterns of dyed Shibori and then compared two groups of patterns in which the samples of one group are stitched by professionals and those of another group stitched by amateurs. Then we predicted that stripe of Mokumenui-shibori is driven only three patterns of stitching condition. To verify our supposition, we made original computer program and simulated five types of simple Shibori pattern which we think ahead. In this program, we gained every correct pattern. To gain a real image of Shibori pattern, we measured two cases of the width of Shibori pattern stripe. One is the width of stripe which is dyed in dark (black), and other one is dyed in light (gray). We understood that, the distribution curve of the black width is showed liner equations which has same slope and the distribution curve of the gray width is showed one liner equation. We set those equations in our program and simulated all samples. As a result, we gained all most same images in CG and confirmed their patterns. About $95 \%$ of direction of each stripe was correct.
\end{abstract}

(Received 8 March, 2007 ; Accepted 24 May, 2007)

\section{1. 緒 言}

絞りは模様染めとしてはもっとも原始的なものであり， 古くから世界各地で行なわれてきた。 日本での絞りは, 奈良時代に中国系の頻纐が行なわれたが，あまり発展せ ず平安・鎌倉時代に継承されていった，その後，「辻が花 染め」という絞りを主体とした格調の高い染色技術が完 成された．江戸時代に入り、絞りの技術は友禅染めや刺 紼とともにますます精細で技巧的なものとなり，京都を 中心とする絹の匹田絞り, 鳴海・有松地方の木綿の絞り (有松絞り)などが行なわれ，その技法の種類も数十種に およんだ。

明治·大正時代以降，東京，大阪，新潟，群馬，秋田， 盛岡など全国各地で産業の一部として絞りが生産されて きたが，伝統工芸品として高い技術を保持し生産されて いるのは京都, 有松・鳴海地方だけであり, 現在でも日 本における絞りの中心をなしている.

しかしながら現在, 有松・鳴海絞りが抱える問題点は 数多く，その中で技術者の高齢化·後継者不足からくる 技術水準の低下や各種絞り技法の消滅は極めて深刻な問
題である.この問題を解決し，有松・鳴海絞りのさらな る展望を望む上で，絞りという伝統工芸の世界にコン ピュータを導入することが問題解決の一つであると考え た.

今日までに，その歴史的背景や絞り技法の種類，染色 法についての研究 $[1,2]$, 絞り柄の発現についての基本的 な技法を用いたサンプル例の報告 $[3,4]$ がみられる. しか しながら, 絞りに打ける柄の発現メカニズムについて理 論的に検討された報告はなく，また絞りという伝統工芸 品をコンピュータという新技術を用いてシミュレーショ ンする試みもなされていない.

本研究では, 絞りの中でも圭目縫い絞りに着目し, 柄 の発現メカニズムの解明とコンピュータによるシミュ レーション・システムを確立させることを目的とした.

ここで圭目縫い絞りとは，5１0mm 間隔で平縫いした あと糸を堅く引き締めて染色したもので，不規則な縦梚 が圭目のようにあらわれる縫い絞りの一種である.

これまでの報告で，柄の発現を左右する針目の間隔に ついて検討し，伝統的な職人の技を明らかにした [5]. 本 報告では，針目と柄の関係を明らかにし、針目から柄を 
シミュレーションする方法を確立した。

\section{2. 絞り柄の予測}

圭目縫い絞りは，白布を平縫いした後に糸を引き締め, 染色を行うと縦方向に圭目状のすじが現れる絞り技法で, 柄は引き締めた時に生じるひだが染色されて発現する. このとき系は布の表面と裏面を交互に通過する.

糸が布の表面に出てくるときの針の貫通穴を『表の針 目』，逆に裏面に出てくるときを『裏の針目』とすると，

『表の針目』一『裏の針目』間の『表の針目間隔』によ る縫い目と，『裏の針目』一『表の針目』間の『裏の針目 間隔』による縫い目が生じる.

柄は『表の針目間隔』から作られる“表の柄”と，『裏 の針目間隔』作られる“裏の柄”に分けることができ, 柄が交わることはない．このことから柄の予測には, “表 の柄”, “裏の柄”を分けて考えればよい。 また, 柄は平 縫いを引き締めた時のひだの先端が染色されることから， 針目間隔のほぼ央に位置すると考えられる。

実際の絞り柄に基づき，隣り合う 2 行の針目から柄が 発現する方向を決定するため, Fig.1に示したような3つ の仮定を立てた。

1）前後の平縫い行で, 表の縫い目同士もしくは裏の 縫い目同士の針目間隔が重なる場合

この場合は重なり量の多い方向に柄が発現する.

2）前後の平縫い行で, 表の縫い目同士もしくは裏の 縫い目同士の針目間隔が重ならない場合

この場合は離れ量の少ない方向に柄が発現する.

3）表の柄と裏の柄で，1）と2）の条件が交差した場合 この場合は，1)の仮定が優先される.

な抢，Fig.1 中の○印は針目を示し，実線打よび破線の 直線は表打よび亭の針目間隔を表す。

本研究ではこれらの仮定に基づく柄の予測をパソコン 上で行なうため, 次の様な基本動作の予測プログラムを 作成した。

はじめに針目情報を与えるため，針目間隔のデータを CSV 形式ファイル(カンマ区切りテキスト形式)で準備す る.

このファイルを読込み，画面上に針目をプロットする.

入力された針目データから表の針目間隔打よび裏の針 目間隔に分けてメモリし，それぞれのデータ毎に各針目 間隔に打ける柄を前述の仮定 1），2）に基づき予測する.

針目間隔の一方が重なり他方が重ならない場合, 重なる 側への柄が優先される.

最後に，表の予測柄および䯧の予測柄を先の針目に重 ねて表示し，両者が交差する部分については仮定3）に基 づき一方のみを表示する处理を行う.

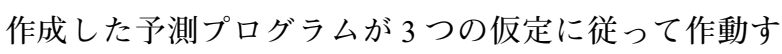

Case 1) Same side of stitch is overlapped.

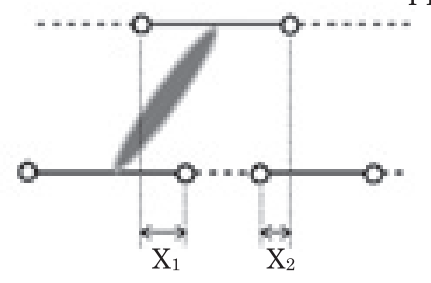

$\mathrm{X}_{1}>\mathrm{X}_{2} \quad$ : Pattern appear at more overlapped side.

Case 2) Same side of stitch is not overlapped.

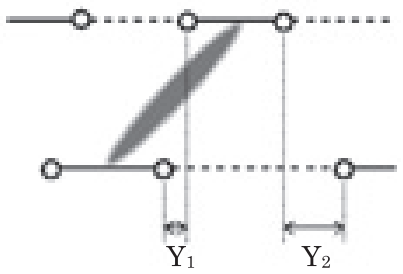

$\mathrm{Y}_{1}>\mathrm{Y}_{2} \quad$ : Pattern appear at closer side.

Case 3) Mixed case with 1) and 2).

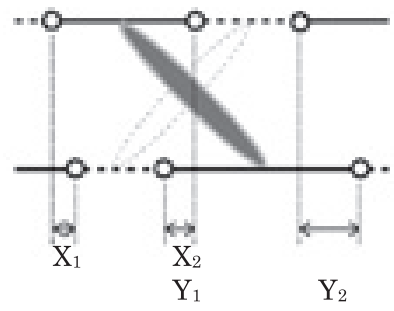

1) $X_{1}<X_{2}$

2) $\mathrm{Y}_{1}<\mathrm{Y}_{2} \quad$ : Case 1) precedes case 2).

Fig. 1 Three patterns of stitching condition.

るかをチェックするため, 出現する可能性のある 5 種類 の針目を人工的に作成し柄の予測を行なった.

1）前後の平縫い行で，全て同じ針目間隔の場合 単純チェックとして、表および裏の針目間隔を 正しく独立した柄予測できているかを確認する事 例.

2）前後の平縫い行で, 針目間隔が一方にずれる場合 表抢よび裏の針目間隔で, 一方が重なり他方が 重ならない場合の事例.

3）前後の針目間隔が等しく重なる場合 仮定 1)の特異ケースで，両方に柄が予測される 事例.

4）前後の針目間隔が異なる長さで重なる場合 仮定 1)を正しく予測する事例.

5）前後の針目間隔が重ならない場合で，かつ表の柄 と亭の柄が交差する場合

仮定 2) を予測した後に，仮定 3)に基づき仮定 1) が優先される事例.

Fig. 2 に人的に作成した柄と針目を示す。 ○印が針目 を表し，その上に記した值が平縫い方向の針目の座標值 $(\mathrm{mm})$ を示している. 予測プログラムにはこの座標值を針 目データとして入力した.

Fig.3 は予測プログラムで得られた結果を示す. 
1) Length of stitch is same.
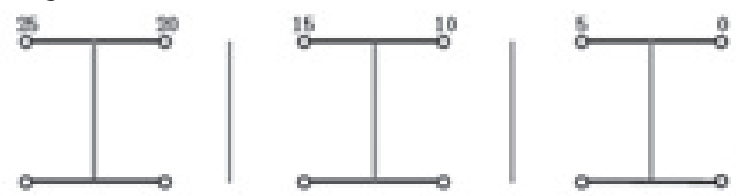

2) One side of stitch is overlapped.

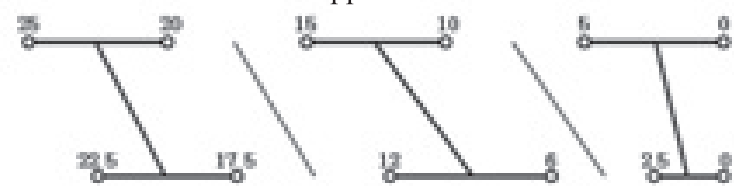

3) Both sides of stitch are overlapped. (Same length)

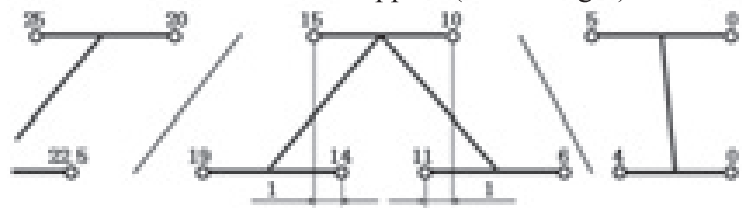

4) Both sides of stitch are overlapped. (Different length)

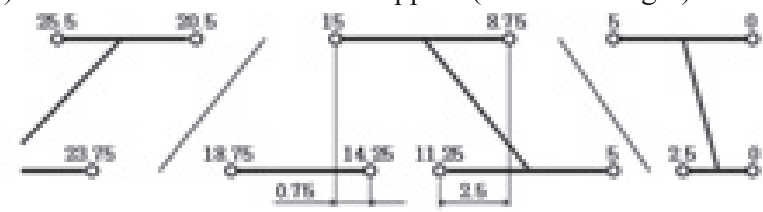

5) Both sides of stitch are not overlapped and mixed case.

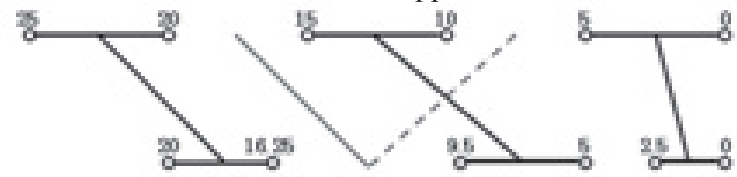

Fig. 2 Predicted five types of simple pattern.

両者を比較し，全ての場合で一致し，作成した予測プ ログラムに誤りがないことを確認した.

\section{3. 柄のシミュレーション}

\section{1 柄の幅の測定}

実際の絞りでは柄に明らかな太さが存在し，柄の幅を 拡大すると強く染色されている部分とにじみにより弱く 染色されている部分がある. 本研究では予測プログラム の描画に柄の幅を組み込むことで，より実物に近い柄の イメージを再現できると考え，柄の幅の測定を行なった.

これまでの報告で用いた同じ材料，同じ染色条件で作 成された 9 種類の試料のうち，玄人が平縫いを行った 3 種類に，比較的針目間隔の分布が玄人に似ている素人の 1 種類を加え，全 4 種類の試料に対し柄の幅を測定した. ここで, 実際の試料の柄の幅には, 『淡い $\rightarrow$ 濃い $\rightarrow$ 淡い』 の濃淡変化が見られる.しかし，測定者の目でこの色の 変化を画一的に測定することは困難なため, 試料の画像 データを黒，灰，白の 3 色に変換し，それぞれの幅を測 定することとした．柄の幅の測定について，針目間隔の 測定と同様, 画像データのドットを数える方法で行なっ た。

画像データを白一黒拈よび白一灰の 2 值化画像とし,
1) Length of stitch is same.

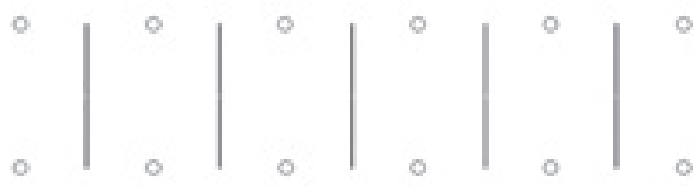

2) One side of stitch is overlapped.

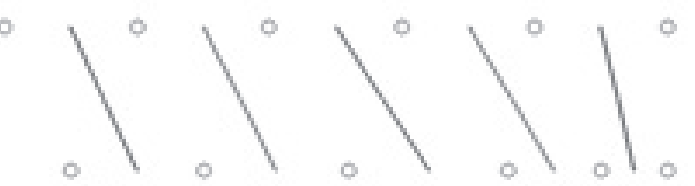

3) Both sides of stitch are overlapped. (Same length)
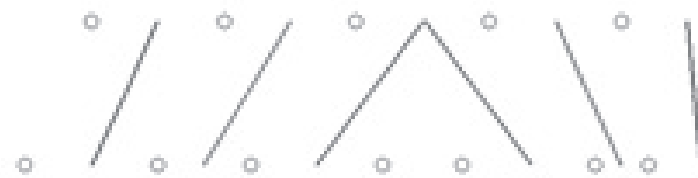

4) Both sides of stitch are overlapped. (Different length)
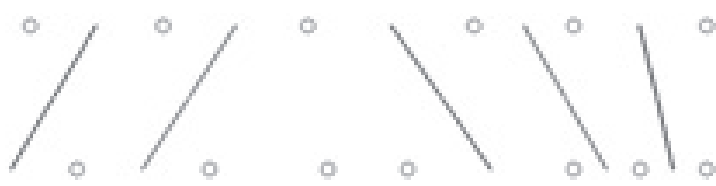

5) Both sides of stitch are not overlapped and mixed case.

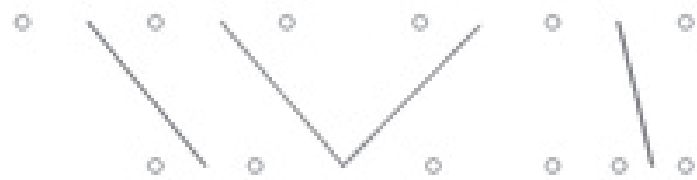

Fig. 3 Simulated results of five patterns.

それぞれ黒の柄の幅と扊の柄の幅を測定した。

2 值化する際のしきい值については，全試料のカラー マップ分布から黒色は99, 灰色は169を固定值とした。 本研究で用いた画像処理ソフトでは，設定したしきい值 で色の反転処理を行うため，しきい值の近傍処理は行わ

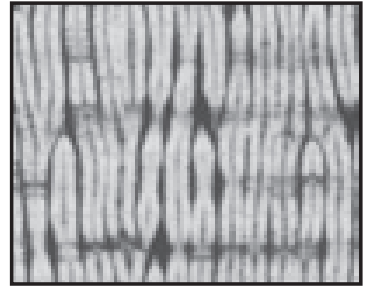

Original Image

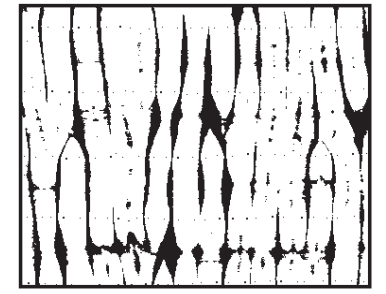

White - Black (Threshold: 99)

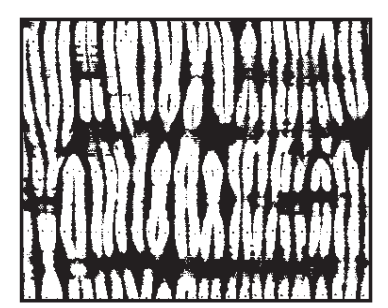

White - Gray

(Threshold:169)
Fig. 4 Sample image of White-Black and White-Gray. 


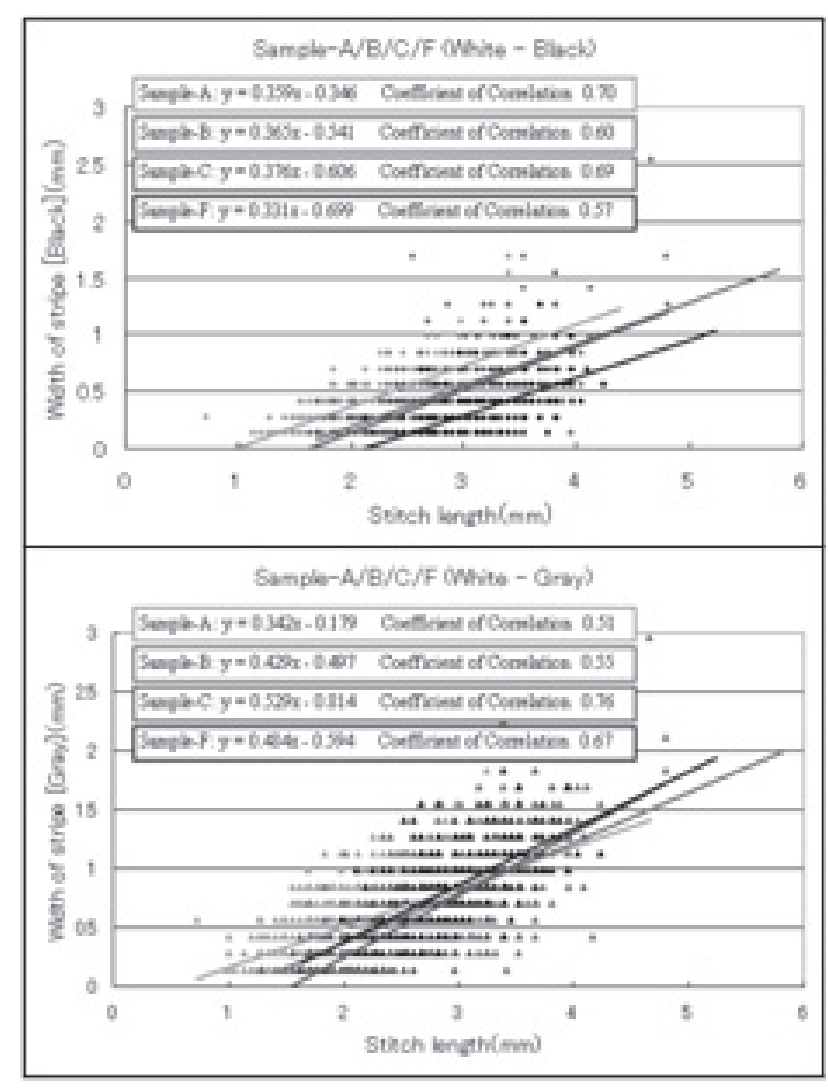

Fig. 5 Correlation stitch length of stripe width.

れていない.

Fig.4 に白一黒打よび白一灰に 2 值化した画像を示す. 2 值化した画像データを用いて, 試料 A, B，C および $\mathrm{F}$ について，黒の柄の幅と扊の柄の幅を測定した．針目間 隔に対する黒の柄の幅および死の柄の幅をプロットした 結果を Fig.5 に示す.なお，Fig.5に示した針目間隔は, 測定したドット数を画像解像度を用いて $\mathrm{mm}$ に換算して いる.

黒の幅と針目間隔には相関があり，それぞれの試料は， 切片の異なる等しい傾きの回帰直線で表すことができる. 一方，灰の幅は黒の幅ほど強くないものの相関が見られ， 試料毎の回帰直線がほぼ同じであることがわかった。

これらの関係から同じ針目間隔であっても，黒の柄の 幅は試料毎の針目間隔に影響され值が異なり，また，灰 の柄の幅は試料毎の固有值には依存せず，単純に針目間 隔との直線関係にあるといえる.

前章で述べた通り, 柄は平縫い後に糸を引き締めて生 じるひだが染色されて発現する.濃く染色される部分は, ひだの頂部である. 異なる試料において, 同じ長さの針

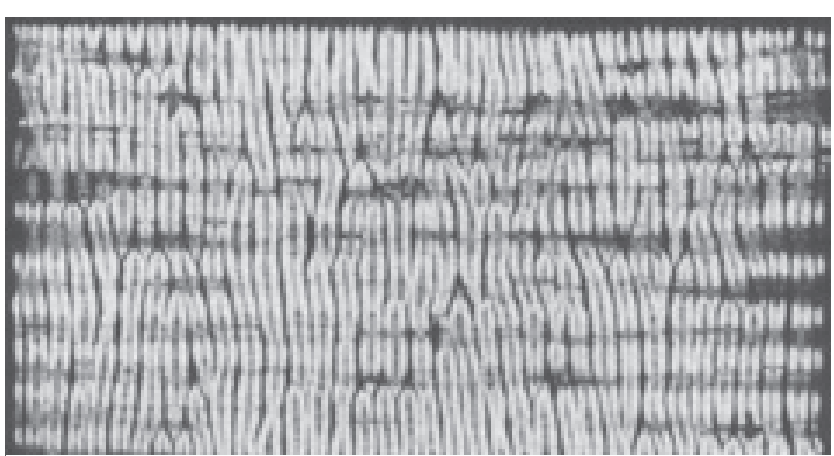

a) Picture of Mokumenui-shibori.

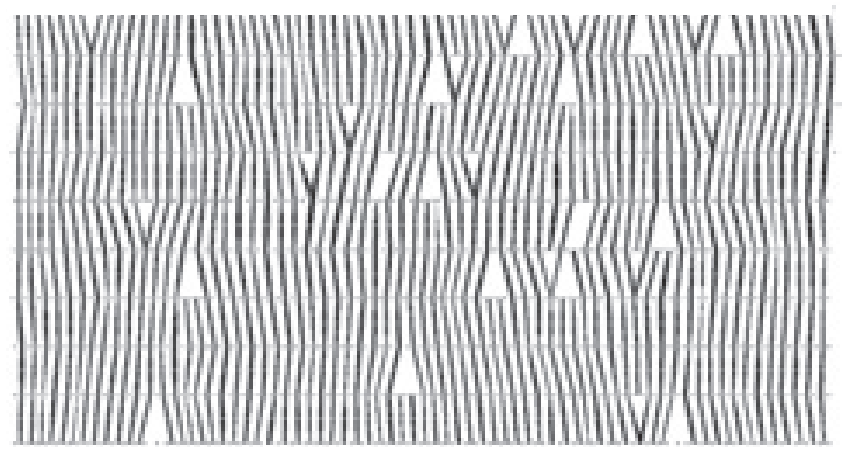

b) Result image of simulation program.

Fig. 6 Result of simulation program.

目間隔の部分に着目した場合，試料自体の針目間隔の平 均が大きいときには, 直接染色されるひだの頂部の突出 が周井のひだと相対的にあまりかわらず，結果的に染色 される柄は細くなる. 反対に試料自体の針目間隔の平均 が小さいときには，ひだの頂部の突出が周囲のひだに比 べ相対的に大きくなり，柄は太い幅になると考えられる.

また淡く染色される部分は，引き締まったひだの内部 へのにじみ部分であるため，試料毎の針目間隔の平均に は影響されず，ひだの部分の針目間隔にのみ依存すると 考えられる.

\section{2 柄のシミュレーションと考察}

前項で得られた結果に基づいて，予測プログラムに用 いるための針目間隔と柄の幅との関係式を求めた。灰の 幅については, Fig.5 で示した散布図においての全測定デー タを用いて回帰直線を求めた。 また黒の幅については 4 試料の回帰直線を考慮し, 傾きについては 4 試料の傾き の平均值 0.358 の一定とした. 切片については各試料の針 目間隔の平均值との比較，検討をしたところ，各試料の 針目間隔の平均值を $\mathrm{t}$, 各回帰直線の切片を $\mathrm{u}$ とすると, 次の式(1)を得た。

Table 1 Rate of correction in simulated Shibori pattern.

\begin{tabular}{cccc|cccccc}
\hline & \multicolumn{3}{c|}{ Stitched by Professionals } & \multicolumn{6}{c}{ Stitched by Amateurs } \\
\cline { 2 - 11 } & A & B & C & D & E & F & G & H & I \\
\hline Number of Stitch Holes & 854 & 616 & 678 & 532 & 516 & 644 & 680 & 558 & 610 \\
\hline Number of Wrong Directions & 41 & 41 & 31 & 14 & 17 & 36 & 48 & 19 & 53 \\
\hline Rate of Correct (\%) & 95.2 & 93.3 & 95.4 & 97.4 & 96.7 & 94.4 & 92.9 & 96.6 & 91.3 \\
\hline
\end{tabular}




$$
u=0.213 \cdot t
$$

したがって，針目間隔と柄の幅との関係式は以下のと おりとなる。

$$
\begin{aligned}
& \text { 黒の幅 : } y=0.358 x-\{(\text { 針目間隔の平均 }) \times 0.213\} \\
& \text { 灰の幅 }: y=0.383 x-0.336
\end{aligned}
$$

前述した予測プログラムにこの式 (2)，（3）を組み込み， 9 種類の試料について各試料の針目間隔の測定データを用 いて柄の予測を行なった.

Fig.6 に試料 B の a) 実物の圭目縫い絞り画像と, b) 予測 プログラム結果をそれぞれ示す.

全ての試料において，実物のイメージに近い予測結果 が得られた. そこで, 次式 (4)で求める值を正解率とし, 実物と予測した柄との検証を行なった。

$$
\text { 正解率 }(\%)=\left(1-\frac{\text { 間違いの柄の箇所 }}{\text { 針目数 }}\right) \times 100
$$

試料毎の針目数と間違い数, 正解率をまとめた結果を Table 1 に示す. 全ての試料において正解率が $90 \%$ 以上で, 平均で約 $95 \%$ の正解率を得た。

本研究で作成した予測プログラムの柄決定アルゴリズ ムは, Fig.1で示したとおり前後の針目行における針目位 置の相対関係が重要となる。ささに，表の針目と裏の針 目を分けてメモリし，それぞれ独立して柄の発現する方 向を決定しているため, 入力データに打ける針目の欠落 (針目の入力漏れ) は，その後の針目間隔のメモリに表董 の入れ違いを生じさせてしまう. したがって，入力され る針目間隔のデータが予測する柄の正解率を大きく左右 するため，正確な針目間隔データが必要となる.

本研究では，これまでの報告で作成した針目間隔デー タ(針目の位置およびその数が正確に入力されたもの)を 用いた。 このデータに対し，前章で示した 3 つの仮定を 予測プログラムにより忠実に適用させた結果, Table 1 に 示す高い正解率が得られたと考えられる.

\section{4. 結言}

本研究では圭目縫い絞りについて, 柄の発現メカニズ ムを明らかにするとともに，コンピュータ(パソコン)に よる柄の予測システムを確立することを目的とした。

得られた結果をまとめると次のようになる.

1）圭目縫い絞りの柄を針目から予測する方法を明らか にし，この方法に基づく予測プログラムを作成した。

2）予測プログラムに対し，出現する可能性のある 5 種 類の針目間隔を与えたところ，全ての場合で一致す る結果が得られた。

3）柄の濃淡の幅を測定した結果，濃い柄の幅は針目間 隔と相関が見られ、試料毎に異なる切片を持つ等し い傾きの回帰直線で表すことができた。また淡い柄 の幅は濃い柄ほど強くないものの針目間隔との相関 が見られ，各試料に共通の回帰直線で表すことがで きた.

4）予測プログラムに柄の濃淡の関係を組み込みシミュ レーションを行なった結果，実際に近いイメージの 柄を得ることができ，正解率は平均 $95 \%$ を得た.

コンピュータ上で柄のシミュレーションができること で，絞りという伝統工芸に新分野を切り開くことができ， 現在深刻な問題となっている後継者不足や伝統技術の途 絶に対する対応策の一つとなり得ると考える.

\section{References}

1. I. Sugita, "Arimatsu Narumi Shibori", Bulletin of Sugino Women's College, Sugino Women's Junior College, 23, p.1-45 (1986).

2. I. Sugita, “Arimatsu Narumi Shibori(Contd.)”, Bulletin of Sugino Women's College, Sugino Women's Junior College, 24, p.1-38 (1987).

3. Y. Hayakawa, Sensyoku a, 198, p.62-63 (1997).

4. Y. Hayakawa, Sensyoku a, 200, p.54-57 (1997).

5. T. Uchida, M. Okamura, A. A. Merati, and Y. Uchita, The $8^{\text {th }}$ ASIAN TEXTILE CONFERENCE, 60 (2005). 